\title{
INTERGENERATIONAL CLIMATE MENURUT GENERASI X DAN GENERASI Y PADA KARYAWAN PT. TI
}

\author{
Vida Jessica Yosefina dan Megawati Batubara \\ Fakultas Psikologi, Universitas Padjadjaran \\ Jalan Raya Bandung-Sumedang KM 21 Jatinangor, Sumedang, 45363 \\ Email: vijessica.yo601@gmail.com
}

\begin{abstract}
ABSTRAK
Perbedaan generasi dalam lingkungan kerja yang sama dapat menjadi sesuatu yang menguntungkan, tetapi di saat yang sama juga dapat menghadirkan tantangan bagi organisasi karena setiap generasi memiliki karakteristik khas yang berbeda satu sama lain. Fenomena ini terjadi di PT. TI, di mana saat ini karyawan aktif di sana terdiri dari empat generasi berbeda. Ketika seluruh generasi diharuskan untuk bekerja dalam lingkungan kerja yang sama, maka dapat terbentuk intergenerational climate. Keberagaman karakteristik masing-masing generasi diasumsikan akan menyebabkan intergenerational climate yang dipersepsikan oleh tiap-tiap generasi pun dapat beragam. Penelitian ini bertujuan untuk menggambarkan intergenerational climate menurut generasi $\mathrm{X}$ dan generasi $\mathrm{Y}$. Rancangan penelitian ini adalah noneksperimental kuantitatif dengan metode studi deskriptif. Penelitian ini dilakukan pada 80 orang karyawan generasi X dan 65 orang karyawan generasi Y dengan metode cluster sampling. Intergenerational climate diukur menggunakan Workplace Intergenerational Climate Scale yang telah diadaptasi ke Bahasa Indonesia. Hasil penelitian menemukan bahwa tidak terdapat perbedaan persepsi terkait intergenerational climate yang tercipta baik itu menurut generasi X ataupun generasi Y pada karyawan PT. TI $(\mathrm{p}=.04)$, di mana mayoritas responden dari kedua generasi memersepsikan intergenerational climate yang tercipta menyenangkan. Temuan ini membuktikan bahwa walaupun terdapat keberagaman karakteristik pada generasi yang berbeda, dinamika kerja antargenerasi yang tercipta dapat dipersepsikan secara sama oleh mayoritas karyawannya, yaitu dipersepsikan secara menyenangkan. Subskala yang paling mendasari intergenerational climate yang dipersepsikan menyenangkan adalah subskala workplace generational inclusiveness. Ditemukan pula bahwa terdapat pengaruh subskala intergenerational climate terhadap intergenerational climate yang tercipta, dan subskala yang memiliki kontribusi terbesar dalam penelitian ini adalah subskala intergenerational contact.
\end{abstract}

Kata kunci: intergenerational climate; generasi X; generasi Y; karyawan; Workplace Intergenerational Climate Scale

\section{INTERGENERATIONAL CLIMATE ACCORDING TO GENERATION X AND Y EMPLOYEES OF PT. TI}

\begin{abstract}
Generational differences in the same work environment can be beneficial, but at the same time can present challenges because each generation has unique characteristics. This phenomenon occurs at PT. TI, where currently active employees consist of four different generations. When all of these generations are required to work in the same environment, an intergenerational climate can be formed. Differences in characteristics between generations are assumed to cause the intergenerational climate that is perceived by each generation to vary. This study aims to describe the intergenerational climate according to generation $X$ and $Y$. The design of this research is nonexperimental quantitative, with descriptive study method. The study was conducted on 80 employees of generation $X$ and 65 employees of generation Y by using cluster sampling technique. Intergenerational climate is measured using the WICS which has been adapted to Indonesian. The results found that there were no differences in perceptions related to the intergenerational climate according to generation $X$ or $Y$, where the majority of both generations perceived a favorable intergenerational climate. This finding shows that although there are different characteristics between different generations, the intergenerational work dynamics created can still be perceived as the same. The workplace generational inclusiveness subscale becomes the subscale that most underlies the perceived favorable intergenerational climate. It was also found that there is an influence of the intergenerational climate subscale on the created intergenerational climate and the intergenerational contact subscale has the largest contribution.
\end{abstract}

Keywords: intergenerational climate; generation X; generation Y; employee; Workplace Intergenerational Climate Scale 


\section{PENDAHULUAN}

Perbedaan generasi telah menjadi salah satu isu mendasar dalam hal angkatan kerja. Hal ini dapat menjadi sesuatu yang menguntungkan karena dapat memperkaya perusahaan serta menciptakan lingkungan kerja yang saling melengkapi, di mana karyawan dari berbagai generasi dapat membawa beragam keterampilan yang saling melengkapi satu sama lain (Sanner-Stiehr \& Vandermause, 2017). Selain itu, interaksi antara karyawan dari generasi yang berbeda dapat memberikan peluang yang besar untuk saling belajar melalui proses transfer learning dua arah (Burmeister dkk., 2018). Hal ini dikarenakan karyawan dari generasi yang berbeda tentunya memiliki pengetahuan dan pengalaman yang beragam pula. Misalnya, karyawan dari generasi yang lebih muda yang lebih melek teknologi dapat menunjukkan kepada generasi yang lebih tua bagaimana cara menggunakan software komputer terbaru, sementara generasi yang lebih tua dapat berbagi pengetahuan khusus terkait perusahaan mereka, ataupun mencontohkan cara yang selama ini mereka gunakan untuk menyelesaikan pekerjaan di perusahaan yang telah terbukti berhasil kepada generasi yang lebih muda.

Namun di saat yang sama, perbedaan generasi dalam lingkungan kerja yang sama juga seringkali menghadirkan tantangan bagi perusahaan karena hal ini dapat menjadi kesenjangan yang berpotensi membuat konflik antargenerasi, misalnya kurangnya pemahaman akan satu sama lain, komunikasi yang terganggu, bahkan penurunan produktivitas. Hal ini dikarenakan setiap generasi memiliki karakteristik yang berbeda-beda (Sanner-Stiehr \& Vandermause, 2017). Manheim (1952) mengungkapkan bahwa generasi yang lebih muda seringkali tidak dapat bersosialisasi dengan sempurna dalam suatu lingkungan kerja karena adanya kesenjangan antara nilai-nilai ideal yang diajarkan oleh generasi yang lebih senior dengan realitas yang dihadapi oleh generasi muda tersebut. Selain itu, kesenjangan dalam faktor usia antara senior dengan yang masih berusia 20 sampai dengan 25 tahun, selain itu menurut Gravett dan Throckmorton (2007), akan menghasilkan adanya keberagaman terkait cara berpikir, kebiasaan, sikap, dan tindakan sehingga lingkungan kerja tersebut akan mengalami kerentanan dalam hal komunikasi yang menjadi awal munculnya konflik antargenerasi. Banyak peristiwa miscommunication atau kesalahpahaman yang terjadi di lingkungan kerja akibat dari adanya perbedaan generasi. Sebagai contoh, generasi yang lebih muda yang sudah banyak menggunakan teknologi lebih suka untuk menyimpan data-data mengenai pekerjaannya dengan cloud computing, sehingga membuat mereka lebih sering menggunakan mobile phone ketika bekerja dibandingkan dengan generasi yang lebih tua. Perilaku ini terkadang disalahartikan oleh atasan atau seniornya, dikarenakan seniornya memegang nilai-nilai tertentu yang membuat mereka beranggapan bahwa generasi yang lebih muda tersebut sangat senang bermain mobile phone saat bekerja. Padahal, yang sebenarnya terjadi adalah generasi yang lebih muda menggunakan mobile phone tersebut untuk mengakses informasi terkait pekerjaannya, hanya saja dengan cara yang menurut mereka paling nyaman untuk dilakukan. Kesenjangan yang tercipta seperti ini seringkali berujung pada ketidakharmonisan dalam bekerja, bahkan hingga dapat berpengaruh pada kinerja organisasi.

Terdapat beberapa teori yang membahas interaksi antargenerasi dalam lingkungan kerja yang sama. Salah satunya adalah perspektif intergenerational climate yang membahas bagaimana dinamika kerja antargenerasi dalam organisasi atau tempat kerja berhubungan dengan sikap terhadap anggota dari berbagai generasi yang berbeda (King \& Bryant, 2017). Dalam perspektif ini, climate yang terbentuk tidak hanya terkait dengan praktik dan kebijakan yang diterapkan oleh organisasi, tetapi juga melalui persepsi dan sikap terhadap orang-orang dari seluruh generasi lain setiap harinya. Intergenerational climate yang tercipta dapat memengaruhi beberapa hal, salah satunya yaitu organizational commitment yang dimiliki oleh anggota organisasi (Agu, 2015). Apabila intergenerational climate dipersepsikan menyenangkan oleh anggota organisasi, maka besar kemungkinan anggota organisasi tersebut akan memiliki komitmen yang tinggi terhadap organisasi. Selain itu, berdasarkan penelitian Lagacé dkk (2019), ditemukan pula bahwa intergenerational climate secara tidak langsung memengaruhi kepuasan kerja. Intergenerational climate yang sehat dapat memberikan dampak yang positif terkait bagaimana karyawan memandang, berempati, serta bersikap terhadap generasi yang berbeda di tempat kerja di mana hal ini secara signifikan dapat meningkatkan kepuasan kerja, terutama bagi karyawan yang lebih tua.

Terdapat lima subskala intergenerational climate menurut King dan Bryant (2017). Subskala yang pertama adalah generational stereotypes yang menekankan persepsi individu terkait apakah terdapat stereotip tertentu terhadap generasi lain selain generasi individu. Kemudian, subskala yang kedua adalah intergenerational affect yang menekankan persepsi individu terkait apakah interaksi dengan karyawan yang berasal dari generasi berbeda membawa pengaruh positif atau negatif bagi dirinya. Lalu, subskala yang ketiga adalah intergenerational contact yang menekankan persepsi individu terkait seberapa sering individu 
bertemu, berinteraksi, membangun hubungan, dan bekerja sama dengan karyawan yang berasal dari generasi berbeda. Subskala yang selanjutnya adalah workplace generational inclusiveness yang menekankan persepsi individu terkait apakah dalam organisasi tercipta lingkungan yang kohesif oleh karena adanya nilai-nilai dan pemahaman bersama antara karyawan yang berasal dari generasi berbeda. Subskala yang terakhir adalah workplace intergenerational retention yang menekankan persepsi individu terkait apakah karyawan dari generasi berbeda membuat individu memilih untuk bertahan atau meninggalkan posisinya dalam perusahaan.

Berdasarkan subskala yang dipaparkan sebelumnya, intergenerational climate dapat dipersepsikan menyenangkan apabila tidak ada stereotip di antara karyawan terkait generasi lain, interaksi antara karyawan yang berasal dari generasi berbeda membawa pengaruh positif bagi satu sama lain, kemudian dalam perusahaan tercipta lingkungan yang kohesif oleh karena adanya nilai-nilai dan pemahaman bersama antara karyawan yang berasal dari generasi berbeda, serta karyawan dari generasi berbeda membuat satu sama lainnya memilih untuk bertahan dalam posisinya masing-masing. Hal-hal tersebut akan berlaku sebaliknya apabila intergenerational climate dipersepsikan tidak menyenangkan.

Berdasarkan Badan Pusat Statistik (2020), diketahui bahwa penduduk usia kerja di Indonesia saat ini adalah penduduk berumur 15 tahun atau lebih. Terhitung Februari 2020, tenaga kerja di Indonesia didominasi oleh penduduk yang berusia 30 sampai dengan 60 tahun. Mengacu pada hal tersebut, akan sangat mungkin bahwa dua sampai dengan empat generasi berbeda diharuskan untuk bekerja dalam satu lingkungan kerja yang sama. Dengan kata lain, fenomena terkait perbedaan generasi dapat diasumsikan menggejala di organisasi atau perusahaan yang anggotanya terdiri dari berbagai generasi.

Salah satu perusahaan yang karyawannya terdiri dari beberapa generasi berbeda adalah PT. TI. Terhitung tahun 2019, PT. TI memiliki jumlah karyawan aktif sebanyak 24,272 karyawan. Usia keseluruhan karyawan tersebut bervariasi, mulai dari 21 tahun sampai dengan 56 tahun. Dengan kata lain, saat ini karyawan aktif yang bekerja di PT. TI terdiri dari generasi baby boomer, generasi X, generasi Y, dan generasi Z.

Berdasarkan hasil penelitian Lavoie-Tremblay dkk. (2010), ditemukan bahwa karena tiap generasi memiliki kekhasan dan karakteristik yang berbeda-beda, keberagaman karakteristik ini dapat menyebabkan perbedaan terkait bagaimana setiap generasi memandang work climate yang tercipta. Namun, belum pernah dilakukan peninjauan lebih lanjut mengenai intergenerational climate secara spesifik terkait apakah intergenerational climate yang tercipta di tempat kerja dapat dipersepsikan secara beragam oleh masingmasing generasi karena adanya karakteristik khas yang dimiliki oleh setiap generasi. Persepsi intergenerational climate yang menyenangkan dapat meningkatkan komitmen dan secara tidak langsung meningkatkan kepuasan kerja yang dimiliki oleh karyawan, sehingga pada akhirnya dapat meningkatkan performa organisasi. Sebaliknya, persepsi intergenerational climate yang tidak menyenangkan dapat meningkatkan tingkat turnover dan memberikan dampak yang negatif terhadap bagaimana karyawan memandang, berempati, serta bersikap terhadap generasi yang berbeda di tempat kerja, sehingga pada akhirnya dapat menurunkan performa organisasi. Dengan demikian, intergenerational climate menjadi penting diteliti untuk mengetahui bagaimana persepsi karyawan terhadap intergenerational climate yang tercipta dalam organisasi serta untuk mengetahui apakah perlu diambil langkah tindak lanjut dalam organisasi terkait dinamika kerja antargenerasi yang tercipta. Tujuan dari penelitian ini adalah untuk melihat apakah terdapat perbedaan intergenerational climate yang dipersepsikan oleh masing-masing generasi, serta untuk melihat bagaimana dinamika kelima subskala intergenerational climate yang tercipta. Adapun hipotesis dalam penelitian ini adalah: 1) Apakah terdapat perbedaan persepsi terkait intergenerational climate yang tercipta antara generasi X dan generasi Y?; dan 2) Apakah terdapat pengaruh subskala intergenerational climate terhadap intergenerational climate yang tercipta?

\section{METODE PENELITIAN}

Dalam penelitian ini, pendekatan penelitian yang digunakan adalah pendekatan kuantitatif. Rancangan penelitian yang digunakan adalah rancangan noneksperimental, yaitu jenis penelitian deskriptif dengan tujuan memberikan deskripsi atau gambaran akurat mengenai situasi atau fenomena tertentu (Christensen, 2007). Populasi dalam penelitian ini adalah karyawan aktif PT. TI. Adapun populasi sasaran dalam penelitian ini adalah karyawan PT TI. yang termasuk ke dalam generasi X, atau yang lahir di antara tahun 1965 sampai dengan tahun 1980, yaitu sebanyak 106 orang. Kemudian yang termasuk ke dalam generasi Y, atau yang lahir di antara tahun 1981 sampai dengan tahun 1995, yaitu sebanyak 58 orang. 
Pemilihan populasi sasaran ini dikarenakan saat ini mayoritas karyawan aktif PT. TI termasuk ke dalam generasi X dan Y.

Alat ukur yang digunakan untuk menggambarkan intergenerational climate dalam penelitian ini adalah Workplace Intergenerational Climate Scale (WICS), milik King dan Bryant (2017) yang telah diadaptasi ke dalam Bahasa Indonesia. WICS didesain untuk mengukur sikap dan persepsi karyawan mengenai karyawan yang berasal dari generasi yang berbeda di tempat kerja. WICS berbentuk kuesioner yang memiliki total item sebanyak 20 item. Seluruh item tersebut terbagi menjadi lima subskala intergenerational climate. Item-item yang ada berbentuk skala semantic differential dari 1 sampai 4, di mana skala 1 merupakan tingkat yang paling rendah dan skala 4 merupakan tingkat yang paling tinggi. Hasil yang akan muncul dari pengukuran intergenerational climate dengan menggunakan WICS terbagi menjadi dua, yaitu intergenerational climate yang dipersepsikan menyenangkan, dan intergenerational climate yang dipersepsikan tidak menyenangkan Kategorisasi tersebut didapatkan dengan perhitungan berikut:

$$
k=\frac{20-5}{2}=7.5
$$

Berdasarkan perhitungan tersebut, didapatkan kategorisasi skor seperti yang disajikan pada Tabel 1.

Tabel 1. Kategorisasi Skor Alat Ukur

\begin{tabular}{lc}
\hline Rentang Skor & Kategori \\
\hline $4.00-9.99$ & Tidak menyenangkan \\
\hline $10.00-16.00$ & Menyenangkan \\
\hline
\end{tabular}

Uji validitas alat ukur yang dilakukan dalam penelitian ini meliputi content validity. Content validity diperoleh dengan melakukan expert review dengan menggunakan perhitungan CVR dan CVI. Berdasarkan expert review yang dilakukan oleh 2 orang expert, dihasilkan validasi yang menyatakan bahwa alat ukur layak digunakan dengan beberapa perbaikan.

Adapun uji reliabilitas alat ukur dalam penelitian ini dilakukan terhadap 30 orang karyawan yang bukan merupakan responden penelitian, dengan menggunakan metode Cronbach's alpha. Pengujian reliabilitas diperoleh dengan menggunakan program SPSS versi 20.0. Berdasarkan hasil pengujian tersebut, didapatkan hasil Cronbach's alpha sebesar .754 sehingga alat ukur dinyatakan reliabel. Setelah dilakukan pengambilan data, dilakukan kembali uji reliabilitas alat ukur terhadap keseluruhan respons yang ada. Berdasarkan hasil pengujian tersebut didapatkan peningkatan hasil Cronbach's alpha, yaitu menjadi sebesar .842 .

Teknik sampling yang digunakan dalam penelitian ini adalah probability sampling dengan metode cluster sampling. Pengukuran sampel dalam penelitian ini dilakukan dengan menggunakan bantuan program Unpad SAS dengan simpangan baku sesuai Deming's Empirical Rule, yaitu sebesar 3.75, serta skala bound of error sebesar .20. Melalui perhitungan tersebut, didapatkan jumlah sampel yang representatif terhadap populasi generasi $\mathrm{X}$ sebanyak 73 orang dan jumlah sampel yang representatif terhadap populasi generasi Y sebanyak 47 orang. Dengan demikian, jumlah sampel keseluruhan dalam penelitian ini adalah sebanyak 120 orang. Setelah dilakukan pengambilan data, didapatkan jumlah sampel sebanyak 145 orang yang terbagi menjadi 80 orang dari generasi $\mathrm{X}$ dan 65 orang dari generasi $\mathrm{Y}$.

Dalam penelitian ini, langkah pertama analisis data utama dilakukan dengan menguji normalitas data yaitu uji Kolmogorov-Smirnov. Setelah uji normalitas menunjukkan bahwa data berdistribusi normal, selanjutnya data diolah dengan menggunakan uji $\mathrm{T}$ untuk menguji apakah terdapat perbedaan persepsi terkait intergenerational climate antara generasi $\mathrm{X}$ dan generasi $\mathrm{Y}$. Kemudian untuk melihat intergenerational climate yang tercipta, pengolahan data dilakukan dengan menghitung rata-rata keseluruhan item dalam setiap subskala. Setelah itu, rata-rata dari kelima subskala tersebut akan dijumlahkan untuk melihat hasil skor total. Skor total kemudian akan disesuaikan dengan kategorisasi, apakah termasuk ke dalam kategori menyenangkan ataupun tidak menyenangkan. Lalu, terhadap kelima subskala dilakukan uji regresi untuk melihat apakah terdapat pengaruh subskala intergenerational climate terhadap intergenerational climate yang tercipta, serta untuk melihat kontribusi dari masing-masing subskala terhadap intergenerational climate yang tercipta. 


\section{HASIL DAN PEMBAHASAN}

Sebelum melakukan pengolahan data, peneliti memastikan terlebih dahulu apakah data yang diperoleh berdistribusi normal atau tidak. Setelah dilakukan analisis normalitas data, diperoleh hasil sebagaimana tercantum pada Tabel 2 .

Tabel 2. Hasil Uji Normalitas

\begin{tabular}{lc}
\hline Kolmogorov-Smirnov Z & $p$-value \\
\hline .914 & .374
\end{tabular}

Tabel 2 menunjukkan bahwa $p$-value (.374) lebih besar dari $\alpha(.05)$ sehingga $\mathrm{H}_{0}$ diterima, dengan kata lain data berdistribusi normal. Oleh karena itu, selanjutnya peneliti melakukan uji beda dengan menggunakan uji T. Hasil uji beda disajikan pada Tabel 3.

Tabel 3. Hasil Uji Beda

\begin{tabular}{lccc}
\hline Generasi & $\mathrm{M}$ & $\mathrm{SD}$ & p-value \\
\hline Generasi X & 3.16 & .34 & .04 \\
\hline Generasi Y & 2.99 & .35 & \\
\hline
\end{tabular}

Berdasarkan Tabel 3, diketahui bahwa p-value (.04) lebih kecil dari $\alpha$ (.05) sehingga $\mathrm{H}_{0}$ ditolak, dengan kata lain terdapat perbedaan antara data persepsi generasi $\mathrm{X}$ dan generasi $\mathrm{Y}$ terkait intergenerational climate yang tercipta. Generasi X memiliki skor rata-rata 3.16, sedangkan generasi Y memiliki skor ratarata 2.99. Dengan kata lain, skor rata-rata generasi $\mathrm{X}$ lebih tinggi apabila dibandingkan dengan skor ratarata generasi Y.

Kategori intergenerational climate berdasarkan persepsi responden penelitian yang merupakan generasi X disajikan pada Figur 1. Dapat dilihat bahwa mayoritas responden, yaitu sebanyak 98.8\% (79 orang) yang merupakan generasi X memersepsikan intergenerational climate yang tercipta menyenangkan. Sebanyak $1.3 \%$ (1 orang) responden lainnya memersepsikan intergenerational climate yang tercipta tidak menyenangkan.

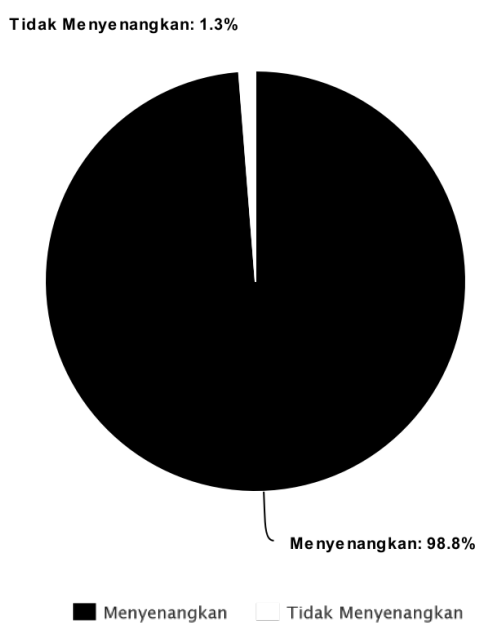

Figur 1. Gambaran Intergenerational Climate menurut Generasi X pada Karyawan PT. TI

Kategori intergenerational climate berdasarkan persepsi responden penelitian yang merupakan generasi Y disajikan pada Figur 2. Dapat dilihat bahwa mayoritas responden, yaitu sebanyak $95.4 \%$ (62 orang) dari responden yang merupakan generasi Y memersepsikan intergenerational climate yang tercipta menyenangkan. Sebanyak 4.6\% (3 orang) responden lainnya memersepsikan intergenerational climate yang tercipta tidak menyenangkan. 


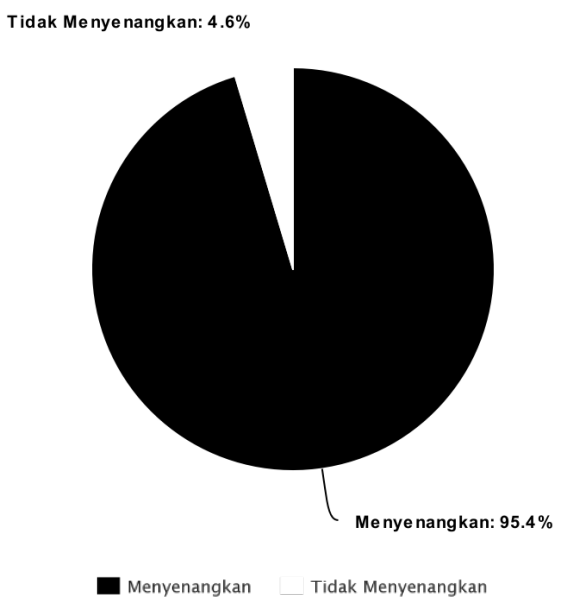

Figur 2. Gambaran Intergenerational Climate menurut Generasi Y pada Karyawan PT. TI

Berdasarkan hasil penelitian yang didapatkan, intergenerational climate yang tercipta dipersepsikan menyenangkan baik oleh mayoritas karyawan, baik itu yang berasal dari generasi $\mathrm{X}$ ataupun generasi Y. Walaupun berdasarkan hasil uji beda ditemukan bahwa terdapat perbedaan antara persepsi generasi $\mathrm{X}$ dan generasi $\mathrm{Y}$ terkait intergenerational climate yang tercipta, namun perbedaan tersebut ternyata tidak signifikan. Temuan pada penelitian ini membuktikan bahwa walaupun terdapat perbedaan cara berpikir, kebiasaan, sikap, tindakan, serta karakteristik-karakteristik lainnya pada generasi yang berbeda, namun dinamika kerja antargenerasi yang tercipta tetap dapat dipersepsikan secara sama oleh karyawan, yaitu dipersepsikan menyenangkan. Dikarenakan hasil yang ditemukan tidak signifikan berbeda, analisis antara generasi $\mathrm{X}$ dan generasi $\mathrm{Y}$ akan dilakukan menjadi satu kesatuan.

Intergenerational climate yang dipersepsikan menyenangkan oleh karyawan membuat PT. TI berbeda dengan organisasi lainnya. Hal ini dikarenakan intergenerational climate yang tercipta akan menjadi ciri khas dari suatu organisasi, yang membedakan organisasi tersebut dengan organisasi lainnya (Wibowo, 2012). Dengan kata lain, apabila nantinya karyawan sudah tidak bekerja lagi di PT. TI, salah satu aspek yang dapat membedakan PT. TI dengan lingkungan kerjanya yang baru adalah dari segi dinamika kerja antargenerasi yang tercipta di tempat kerja.

Berdasarkan Agu (2015), climate dapat memengaruhi beberapa hal, di mana salah satunya yaitu organizational commitment karyawan. Saat ini, diketahui bahwa salah satu pencapaian yang diperoleh PT. TI adalah rendahnya jumlah karyawan yang melakukan turnover. Hal ini membuktikan bahwa intergenerational climate yang dipersepsikan menyenangkan oleh karyawan berhasil membuat karyawan memiliki komitmen yang tinggi terhadap organisasi. Selain itu, hasil penelitian sebelumnya terkait intergenerational climate menemukan bahwa intergenerational climate secara tidak langsung memengaruhi kepuasan kerja karyawan (Lagacé dkk., 2019). Berdasarkan analisis terhadap hasil penelitian, ditemukan bahwa salah satu item yang mendapatkan skor tertinggi adalah item yang mengatakan bahwa "Bekerja dengan rekan kerja dari berbagai generasi berbeda meningkatkan kualitas kehidupan kerja saya." Berdasarkan penelitian Dhamija dkk. (2019), ditemukan bahwa kualitas kehidupan kerja berpengaruh terhadap kepuasan kerja yang dimiliki oleh anggota organisasi. Hal ini membuktikan bahwa intergenerational climate yang dipersepsikan menyenangkan oleh karyawan secara tidak langsung berhasil membuat karyawan memiliki kepuasan kerja yang tinggi. Namun demikian, intergenerational climate bersifat sementara dan dapat berubah. Oleh karena itu, intergenerational climate yang sudah baik saat ini perlu dipertahankan. Hal ini dikarenakan intergenerational climate akan memberi pengaruh besar terhadap efektivitas organisasi dalam mencapai tujuannya. Selain itu, intergenerational climate yang tercipta perlu diusahakan agar dapat selalu dipersepsikan menyenangkan oleh karyawannya sehingga nantinya PT. TI dapat terus maju dan berkembang.

Gambaran subskala intergenerational climate menurut responden penelitian yang merupakan generasi X disajikan pada Figur 3. Dapat dilihat bahwa subskala generational stereotypes memiliki total skor sebesar 11.88, subskala intergenerational affect memiliki total skor sebesar 12.73, subskala intergenerational contact memiliki total skor sebesar 11.63, subskala workplace generational inclusiveness memiliki total skor sebesar 14.25, dan subskala workplace intergenerational retention memiliki total skor sebesar 12.84. Jadi, kelima subskala tersebut dapat dikatakan termasuk ke dalam kategori menyenangkan. 


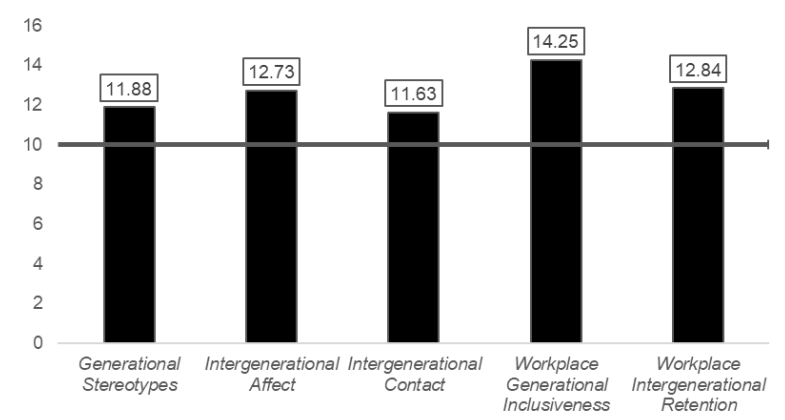

Figur 3. Gambaran Subskala Intergenerational Climate menurut Generasi X pada Karyawan PT. TI

Gambaran subskala intergenerational climate menurut responden penelitian yang merupakan generasi Y disajikan pada Figur 4. Dapat dilihat bahwa subskala generational stereotypes memiliki total skor sebesar 11.37, subskala intergenerational affect memiliki total skor sebesar 12.17, subskala intergenerational contact memiliki total skor sebesar 11.2, subskala workplace generational inclusiveness memiliki total skor sebesar 13.03, dan subskala workplace intergenerational retention memiliki total skor sebesar 12.18. Jadi, kelima subskala tersebut dapat dikatakan termasuk ke dalam kategori menyenangkan.

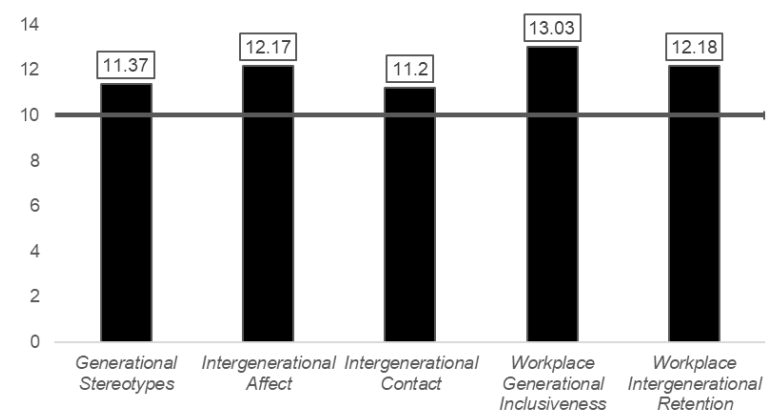

Figur 4. Gambaran Subskala Intergenerational Climate menurut Generasi Y pada Karyawan PT. TI

Intergenerational climate yang dipersepsikan menyenangkan oleh karyawan didasari oleh beberapa hal. Berdasarkan analisis hasil penelitian, ditemukan bahwa alasan-alasan tersebut tidak secara signifikan berbeda antara menurut generasi $\mathrm{X}$ ataupun generasi $\mathrm{Y}$. Hasil yang tidak secara signifikan berbeda ini dapat dijelaskan berdasarkan beberapa hal. Pertama, berdasarkan Martin (2002) organizational climate dikatakan sebagai subculture dalam konsep organizational culture menurut para ahli. Hal ini membuat faktor keunikan perseptual individu yang merupakan anggota organisasi menjadi tidak terlalu menonjol dalam memersepsikan situasi yang sama. Kedua, sesuai dengan pendekatan interaktif, persepsi individu terkait climate akan dipengaruhi oleh situasi yang sama yang dihadapi oleh seluruh individu. Dalam hal ini situasi yang sama meliputi perangkat-perangkat di organisasi, seperti sistem manajemen tempat kerja, aturanaturan yang ada, pola kepemimpinan pimpinan yang menjabat saat ini, dan sebagainya.

Alasan paling kuat mengapa intergenerational climate dapat dipersepsikan menyenangkan oleh karyawan adalah terkait subskala workplace generational inclusiveness, yaitu karena mereka merasa bahwa terdapat nilai-nilai dan pemahaman bersama antara karyawan yang berasal dari generasi berbeda sehingga tercipta lingkungan kerja yang kohesif. Hal ini mengarah pada terciptanya toleransi yang membuat karyawan PT. TI dari generasi yang berbeda saling menghargai dan menghormati satu sama lain walaupun setiap generasi memiliki cara berpikir, kebiasaan, sikap, tindakan, serta karakteristiknya masing-masing. Tidak hanya itu, antara karyawan yang berbeda generasi turut saling membagikan nilai-nilai dan pemahaman bersama agar perbedaan yang ada tidak mengganggu kinerja mereka. Dikarenakan lingkungan kerja yang inklusif menjadi alasan terkuat mengapa intergenerational climate di PT. TI dapat dipersepsikan menyenangkan oleh karyawan, pada akhirnya hal ini dapat menyamakan persepsi seluruh karyawan, baik itu yang termasuk ke dalam generasi $\mathrm{X}$ ataupun generasi $\mathrm{Y}$, terkait intergenerational climate yang tercipta terlepas dari karakteristik generasi karyawan. 
Kemudian, alasan kedua yang terkuat adalah terkait subskala workplace intergenerational retention, yaitu karena berdasarkan hasil penelitian ditemukan bahwa mayoritas atau lebih dari setengah karyawan merasa bahwa karyawan dari generasi berbeda membuatnya memilih untuk bertahan posisinya dalam perusahaan saat ini. Hal ini dikarenakan mereka tidak merasakan adanya tekanan saat bekerja, baik itu dari karyawan lain dari generasi yang lebih tua ataupun lebih muda. Sebaliknya, mereka merasakan adanya dukungan saat bekerja dari rekan kerjanya yang berasal dari generasi berbeda. Hasil penelitian Tinambunan (2019) menemukan bahwa climate dapat dipersepsikan menyenangkan apabila anggotanya melakukan sesuatu yang berguna dan memberikan manfaat bagi dirinya masing-masing. Saling memberikan dukungan untuk bertahan dalam posisinya masing-masing termasuk ke dalam sesuatu yang berguna dan memberikan manfaat bagi masing-masing karyawan satu sama lain. Selain itu, di PT. TI seluruh karyawan memiliki kesempatan yang sama untuk diberikan promosi, terlepas dari usia ataupun generasinya. Kompensasi yang didapatkan oleh masing-masing karyawan pun secara umum telah ditetapkan berdasarkan ketentuan umum jabatan yang dimilikinya, sehingga tidak terdapat kompetisi di antara karyawan dalam hal ini. Oleh karena itu, menurut karyawan lingkungan kerjanya saat ini adalah lingkungan kerja yang sehat bagi segala generasi.

Lalu alasan ketiga yang terkuat adalah terkait subskala intergenerational affect, yaitu karena berdasarkan hasil penelitian ditemukan bahwa mayoritas atau lebih dari setengah karyawan merasa bahwa interaksi antara dirinya dengan karyawan yang berasal dari generasi berbeda membawa pengaruh positif bagi dirinya. Karyawan dari berbagai generasi dapat membawa beragam keterampilan yang saling melengkapi di tempat kerja (Sanner-Stiehr \& Vandermause, 2017), sehingga interaksi antara karyawan dari generasi yang berbeda dapat memberikan peluang yang besar untuk saling belajar melalui proses transfer learning dua arah (Burmeister dkk., 2018). Selain itu, dalam penelitian ini diketahui bahwa interaksi dengan karyawan yang berasal dari generasi berbeda dapat membuat karyawan merasakan adanya kenyamanan, di mana hal ini berdampak baik bagi kehidupan sosial mereka.

Alasan keempat adalah terkait subskala generational stereotypes, yaitu karena berdasarkan hasil penelitian ditemukan bahwa mayoritas atau lebih dari setengah karyawan merasa bahwa tidak terdapat stereotip di antara karyawan terkait generasi lain. Meski demikian, hasil wawancara data awal terhadap beberapa karyawan menunjukkan bahwa terdapat beberapan stereotip terkait setiap generasi di PT. TI. Misalnya, ketika harus berkoordinasi dengan karyawan yang lebih tua, bahkan dari sebelum bekerja, baik karyawan yang berasal dari generasi $\mathrm{X}$ ataupun generasi $\mathrm{Y}$ sudah memiliki keyakinan tersendiri bahwa pekerjaan tersebut akan membutuhkan waktu yang lama untuk maju ke tahap berikutnya. Kemudian setelah koordinasi dengan karyawan yang lebih tua ini dilakukan, diketahui bahwa karyawan memang membutuhkan waktu yang lama untuk menunggu hasil kerja dari karyawan yang lebih tua. Berdasarkan hasil penelitian, stereotip yang paling umum ada di antara karyawan adalah terkait cara bekerja, di mana karyawan merasa bahwa karyawan lain yang berasal dari generasi berbeda cenderung bekerja dengan cara yang berbeda dengan dirinya ataupun dengan karyawan lain yang berasal dari generasi yang sama dengan dirinya. Akan tetapi meski terdapat beberapa stereotip tersebut, koordinasi kerja antara karyawan yang berbeda generasi tetap dapat berjalan dengan baik. Hal inilah yang membuat intergenerational climate tetap dipersepsikan menyenangkan oleh mayoritas karyawan.

Subskala intergenerational contact menjadi subskala yang berada di urutan paling terakhir dalam mendasari intergenerational climate yang dipersepsikan menyenangkan, baik oleh generasi $\mathrm{X}$ ataupun generasi Y. Berdasarkan hasil penelitian, hal ini dapat dikarenakan interaksi di antara mayoritas karyawan dengan karyawan dari generasi berbeda secara umum hanyalah sebatas hal-hal yang terkait dengan pekerjaan. Berdasarkan wawancara data awal terhadap beberapa karyawan, bentuk interaksi tersebut dapat berupa generasi yang lebih tua membagikan cara bekerja yang efektif kepada generasi yang lebih muda, dengan didasarkan pada pengalaman kerja mereka yang sudah lebih lama. Selain itu, generasi yang lebih muda membagikan cara mengoperasikan berbagai teknologi terbaru kepada generasi yang lebih tua, yang dapat membantu dan mengoptimalkan pekerjaan mereka dengan efisien. Apabila dilihat dari karakteristik generasi $\mathrm{X}$ ataupun generasi $\mathrm{Y}$, terdapat beberapa kemungkinan alasan yang dapat mendasari mengapa interaksi antara karyawan yang berasal dari generasi berbeda sebagian besar hanya terkait dengan pekerjaan. Yang pertama, beberapa penelitian sebelumnya menemukan bahwa generasi X secara umum memiliki sikap yang skeptis, tertutup, dan sangat independen (Lancaster \& Stillman, 2002; Tolbize, 2008). Hal ini membuat generasi X kurang melakukan interaksi dengan generasi lainnya di luar hal-hal terkait dengan pekerjaan, karena mereka lebih memilih untuk berfokus pada dirinya sendiri. Selain itu, penelitian sebelumnya juga mengemukakan bahwa generasi $\mathrm{Y}$ cenderung berganti-ganti tempat kerja karena pada generasi ini terdapat beberapa preferensi kerja yang sulit untuk dipenuhi (Tolbize, 2008). Hal ini membuat 
generasi Y menjadi kurang memiliki waktu untuk melakukan interaksi dengan generasi lainnya di luar halhal terkait dengan pekerjaan, karena waktu yang mereka miliki lebih banyak dihabiskan untuk beradaptasi dengan pekerjaan barunya, dibandingkan dengan untuk membangun hubungan informal dengan generasi lain. Meskipun begitu, berdasarkan hasil penelitian diketahui bahwa subskala ini masih masuk ke dalam kategori menyenangkan.

Terhadap kelima subskala dilakukan uji regresi untuk melihat kontribusi dari masing-masing subskala terhadap intergenerational climate yang tercipta, yang disajikan pada Tabel 4. Berdasarkan Tabel 4 , didapatkan $p$-value (.000) lebih kecil dari $\alpha(.05)$ sehingga $\mathrm{H}_{0}$ ditolak, dengan kata lain terdapat pengaruh subskala intergenerational climate terhadap intergenerational climate yang tercipta. Nilai koefisien $R$ Squared digunakan untuk melihat berapa persen pengaruh yang diberikan kelima subskala terhadap intergenerational climate yang tercipta. Berdasarkan nilai $R$-Squared yang didapat, kelima subskala memiliki pengaruh terhadap intergenerational climate sebesar $100 \%$.

Tabel 4. Hasil Uji Regresi terhadap Kelima Subskala Intergenerational Climate

\begin{tabular}{lc}
\hline$R$-Squared & $p$-value \\
\hline 1.000 & .000 \\
\hline
\end{tabular}

Untuk melihat pengaruh masing-masing subskala, dilakukan uji regresi berganda untuk melihat kekuatan korelasi masing-masing subskala. Hasil uji regresi berganda disajikan pada Tabel 5. Berdasarkan Tabel 5, hasil yang diperoleh menunjukkan bahwa kelima subskala dimensi memiliki $p$-value (.000) lebih kecil dari $\alpha$ (.05) sehingga $\mathrm{H}_{0}$ ditolak. Hal ini berarti terdapat pengaruh masing-masing subskala terhadap intergenerational climate yang tercipta. Kontribusi yang diberikan oleh masing-masing subskala yaitu subskala generational stereotypes sebesar $28 \%$, subskala intergenerational affect sebesar $25.6 \%$, subskala intergenerational contact sebesar $34.2 \%$, subskala workplace generational inclusiveness sebesar $28.8 \%$, dan subskala workplace intergenerational retention sebesar $30.8 \%$.

Tabel 5. Koefisien Regresi Berganda Subskala Intergenerational Climate

\begin{tabular}{lcc}
\hline Dimensi & $\beta$ & $p$-value \\
\hline Generational Stereotypes & .280 & .000 \\
\hline Intergenerational Affect & .256 & .000 \\
\hline Intergenerational Contact & .342 & .000 \\
\hline $\begin{array}{l}\text { Workplace Generational } \\
\text { Inclusiveness }\end{array}$ & .288 & .000 \\
\hline $\begin{array}{l}\text { Workplace } \\
\text { Intergenerational }\end{array}$ & .308 & .000 \\
Retention & &
\end{tabular}

Subskala intergenerational contact diketahui memiliki kontribusi terbesar terhadap intergenerational climate yang tercipta dalam penelitian ini. Hal ini berarti semakin sering interaksi dan hubungan kerja sama antara karyawan yang berasal dari generasi berbeda, maka intergenerational climate yang tercipta dapat semakin menyenangkan. Oleh karena itu, perlu ditingkatkan interaksi informal antara karyawan yang berasal dari generasi berbeda agar intergenerational climate yang tercipta dapat semakin dipersepsikan menyenangkan. Misalnya, pihak manajemen dapat melakukan kegiatan gathering, bonding, dan sebagainya.

Subskala intergenerational affect diketahui memiliki kontribusi terkecil terhadap intergenerational climate yang tercipta dalam penelitian ini. Maka dari itu, walaupun interaksi antara generasi yang berbeda seringkali dapat menyebabkan komunikasi antargenerasi yang berbeda terganggu dikarenakan kurangnya pemahaman satu sama lain, namun hal ini tidak secara signifikan membuat intergenerational climate yang tercipta tidak menyenangkan. Selain itu, adanya kenyamanan dalam berinteraksi membuat karyawan menjadi merasa bahwa melalui interaksi tersebut mereka tetap dapat merasakan adanya pengaruh positif bagi dirinya. 


\section{SIMPULAN}

Berdasarkan hasil dan pembahasan yang telah dipaparkan mengenai intergenerational climate menurut generasi $\mathrm{X}$ dan generasi $\mathrm{Y}$, maka dapat disimpulkan bahwa tidak terdapat perbedaan persepsi terkait intergenerational climate yang tercipta baik itu menurut generasi $\mathrm{X}$ ataupun generasi $\mathrm{Y}$ pada karyawan PT. TI, di mana kedua generasi memersepsikan intergenerational climate yang tercipta secara menyenangkan. Artinya, temuan ini membuktikan bahwa walaupun terdapat keberagaman cara berpikir, kebiasaan, sikap, tindakan, serta karakteristik-karakteristik lainnya pada generasi yang berbeda, namun dinamika kerja antargenerasi yang tercipta tetap dapat dipersepsikan secara sama oleh mayoritas karyawannya, yaitu dipersepsikan menyenangkan. Dikarenakan intergenerational climate dipersepsikan secara menyenangkan, maka besar kemungkinan bagi karyawan untuk dapat memiliki organizational commitment yang nantinya dapat meningkatkan performa kerja karyawan serta mendorong keberhasilan PT. TI. Hal ini terbukti melalui salah satu pencapaian yang diperoleh oleh PT TI, yaitu rendahnya jumlah karyawan yang melakukan turnover. Selain itu dengan dipersepsikannya intergenerational climate sebagai menyenangkan, maka besar kemungkinan bagi karyawan untuk dapat memiliki kepuasan kerja yang tinggi. Hal ini pun secara tidak langsung terbukti melalui salah satu item yang mendapatkan skor tertinggi, yang mengatakan bahwa bekerja dengan rekan kerja dari berbagai generasi berbeda dapat meningkatkan kualitas kehidupan kerja karyawan.

Berdasarkan analisis regresi terhadap kelima subskala intergenerational climate, dapat disimpulkan bahwa terdapat pengaruh subskala intergenerational climate terhadap intergenerational climate yang tercipta dan subskala yang memiliki kontribusi terbesar terhadap intergenerational climate yang tercipta dalam penelitian ini adalah subskala intergenerational contact. Artinya, semakin sering interaksi dan hubungan kerja sama antara karyawan yang berasal dari generasi berbeda maka intergenerational climate yang tercipta dapat semakin menyenangkan. Ditemukan pula bahwa subskala yang paling mendasari intergenerational climate yang dipersepsikan menyenangkan adalah subskala workplace generational inclusiveness. Temuan ini mendukung hasil yang didapatkan, yang menunjukkan bahwa hasil menurut generasi $\mathrm{X}$ ataupun generasi $\mathrm{Y}$ tidak secara signifikan berbeda. Dengan kata lain, lingkungan kerja yang inklusif dapat menyamakan persepsi karyawan terkait intergenerational climate yang tercipta, terlepas dari karakteristik generasi karyawan tersebut.

Berdasarkan hasil dan pembahasan penelitian yang telah dipaparkan, terdapat beberapa saran teoretis bagi penelitian selanjutnya yang akan meneliti dengan topik yang sama, yaitu sebagai berikut:

1. Penelitian ini hanya melibatkan karyawan yang termasuk ke dalam unit Divisi Regional III PT. Telkom. Penelitian selanjutnya disarankan untuk meneliti PT. Telkom secara keseluruhan agar hasil yang didapatkan terkait gambaran intergenerational climate dapat lebih komprehensif lagi.

2. Penelitian ini hanya menggambarkan intergenerational climate beserta subskala-subskalanya menurut generasi X dan generasi Y. Penelitian selanjutnya disarankan untuk menggali lebih dalam terkait faktorfaktor apa saja yang mendasari dan/atau dapat mempengaruhi intergenerational climate tersebut.

Adapun saran praktis bagi pihak manajemen, yaitu untuk mempertahankan dan meningkatkan intergenerational climate yang tercipta agar dapat tetap dipersepsikan favorable oleh karyawannya, sehingga nantinya Divisi Regional III PT. Telkom dapat terus maju dan berkembang. Beberapa upaya tersebut yaitu sebagai berikut:

1. Pihak manajemen dapat membuat suatu aktivitas informal di luar hal-hal terkait dengan pekerjaan yang dapat mendorong seluruh generasi untuk dapat terlibat dan beraktivitas bersama-bersama. Misalnya, pihak manajemen dapat melakukan kegiatan gathering, bonding, dan sebagainya.

2. Pihak manajemen dapat melakukan analisis secara berkala terkait stereotip apa saja yang ada di antara karyawan. Ketika ditemukan bahwa stereotip tersebut mengganggu kinerja karyawan, pihak manajemen dapat mencari solusi lalu memberi masukan terhadap generasi terkait agar dapat memperbaiki diri menjadi lebih baik, atau memberi masukan terhadap generasi lainnya mengenai cara efektif untuk dapat bekerja secara objektif walaupun di tengah beberapa stereotip yang dirasakan.

3. Setiap generasi tidak dibeda-bedakan dalam diberi kesempatan promosi oleh pihak manajemen, tetapi yang diutamakan dalam memberikan kesempatan promosi adalah prestasi dan produktivitas kerja karyawan. 


\section{DAFTAR PUSTAKA}

Agu, O. L. (2015). Work engagement, organizational commitment, self efficacy and organizational growth: a literature review. Information Impact: Journal of Information and Knowledge Management, 6(1), 14-29.

Badan Pusat Statistik. (2020). Tenaga Kerja: Konsep/Penjelasan Teknis. Diakses dari https://www.bps.go.id/subject/6/tenaga-

kerja.html\#: :text=Penduduk\%20usia\%20kerja\%20adalah\%20penduduk,sementara\%20tidak\%20 bekerja\%20dan\%20pengangguran.

Burmeister, A., Fasbender, U., \& Deller, J. (2018). Being perceived as a knowledge sender or knowledge receiver: A multistudy investigation of the effect of age on knowledge transfer. Journal of Occupational and Organizational Psychology, 91(3), 518-545.

Christensen, L. B. (2007). Experimental methodology (10th ed.). Boston: Pearson Education, Inc.

Dhamija, P., Gupta, S., \& Bag, S. (2019), Measuring of job satisfaction: the use of quality of work life factors. Benchmarking: An International Journal, 26(3), 871-892.

Gravett, L., \& Throckmorton, R. (2007). Bridging the generation gap: how to get radio babies, boomers, gen xers, and gen yers to work together and achieve more. USA: The Career Press.

King, S. P., \& Bryant, F. B. (2017). The Workplace Intergenerational Climate Scale (WICS): a self-report instrument measuring ageism in the workplace. Journal of Organizational Behavior, 38(1), 124 151.

Lagacé, M., Van de Beeck, L., \& Firzly, N. (2019). Building on intergenerational climate to counter ageism in the workplace? A cross-organizational study. Journal of Intergenerational Relationships, 17(2), 201-219.

Lancaster, L. C., \& Stillman, D. (2002). When generations collide: who they are why they clash. how to solve the generational puzzle at work. New York: Collins Business.

Lavoie-Tremblay, M., Paquet, M., Duchesne, M. A., Santo, A., Gavrancic, A., Courcy, F., \& Gagnon, S. (2010). Retaining nurses and other hospital workers: an intergenerational perspective of the work climate. Journal of Nursing Scholarship, 42(4), 414-422.

Manheim, K. (1952). The problem of generations. In P. Kecskemeti (Ed.), Essays on the sociology of knowledge (pp. 276-320). London: Routledge \& Kegan Paul.

Martin, J. M. (2002). Organizational culture: mapping the terrain. Thousand Oaks: Sage.

Sanner-Stiehr, E., \& Vandermause, R. K. (2017). Can't we all just get along? A dual-theory approach to understanding and managing the multigenerational workplace. Journal of Organizational Psychology, 17(2).

Tinambunan, A. K. (2019). Analisis Iklim Organisasi PT. Sharon. FRIMA: Festival Riset Ilmiah Manajemen dan Akuntansi, (2), 1057-1066.

Tolbize, A. (2008). Generational differences in the workplace. Research and Training Center on Community Living, 5(2), 1-21.

Wibowo, T. S. (2012). Kajian literatur perbedaan budaya dan iklim organisasi. Majalah Ekonomi, 16(1). 